\title{
UMA TEORIA MARXISTA DO POLÍTICO? O DEBATE BOBBIO TRENT'ANNI DOPPO*
}

Alvaro Bianchi

Uma teoria que se constrói como teoria crítica tem a obrigação de ser crítica a seu próprio respeito. Para o marxismo, esse não é penas um imperativo lógico, é uma exigência imposta pela relação tensa que estabelece com uma realidade sempre movente que pretende, ao mesmo tempo, interpretar e transformar. Como programa de pesquisa crítica o marxismo deve questionar-se permanentemente sobre sua eficácia e viabilidade, sobre seu alcance e limites, sobre seus pontos fortes e fracos. Faz isso, submetendo-se a uma permanente reconstrução, colocando-se novos problemas de pesquisa, retomando os antigos à luz dos novos desenvolvimentos teóricos. Para uma teoria crítica, não há, portanto, "ciência normal”, na acepção que Thomas Kuhn atribuía à expressão.

Inexiste razão para o marxismo recusar a pergunta do título ou não aceitar o desafio de respondê-la. Sob a forma de desafio, várias vezes, ela foi formulada. Dessas tantas, merece destaque aquela feita por Norberto Bobbio,

\footnotetext{
* Uma versão resumida deste texto foi apresentada no Colóquio Kairós - Existe uma Teoria Marxista da Política?, realizado na Universidade Metodista de São Paulo em 27 de abril de 2005
} 
trent'anni doppo, em um artigo de grande repercussão, publicado na revista Monodoperaio. "Esiste una dottrina marxista dello Stato?", indagava o filosofo italiano, de modo explicitamente provocativo para, a seguir, responder negativamente à própria pergunta (1975).

Mesmo no contexto italiano, o questionamento de Bobbio e sua resposta não eram verdadeiramente originais e ele próprio reconhecia isso. Lucio Colletti, por exemplo, em sua conhecida entrevista filosófica e política à New Left Review, havia afirmado, um ano antes, "a fragilidade e o desenvolvimento esparso de uma teoria política no marxismo. [...] O marxismo é carente de uma verdadeira teoria política" (Colletti, 1974: 15). Para Colletti, essa ausência seria decorrente da percepção de Marx, partilhada posteriormente por Lenin, de que a transição para o socialismo e a realização do comunismo em escala mundial seria "um processo extremamente rápido e próximo” (Colletti, 1974:).

40 Bobbio não se afastava muito de Colletti, ao responder negativamente sua própria indagação e rejeitar a existência de uma teoria marxista do Estado. As razões para tal negativa, argumentava Bobbio, eram de três ordens: 1) o interesse quase exclusivo por parte do marxismo na questão da conquista do poder e, conseqüentemente, na teoria do partido, mais do que na do Estado; 2) a persistente convicção de que, uma vez conquistado o poder, o Estado seria um fenômeno de "transição" e que, portanto, a reflexão sobre esse fenômeno logo seria ultrapassada pelo fim do Estado e da política; e 3) o abuso do princípio de autoridade, que provocaria um vazio teórico, preenchido com a enésima exegese "daquelas vinte páginas de Marx, já viradas e reviradas de todo lado” (Bobbio, 1975: 26).

Há nessa enumeração aparentemente simples um sutil jogo de palavras sobre o qual é importante chamar a atenção. Destaco aqui duas identidades afirmadas, mas não desenvolvidas por Bobbio. Na primeira dessas identidades, a ausência de uma teoria (dottrina) marxista do Estado equivaleria à "inex- 
istência, ou insuficiência, ou deficiência, ou irrelevância de uma ciência política marxista" (Bobbio, 1975: 24). Sobre ela, há pouco a dizer. Para o marxismo, a política é o lócus dos conflitos pela apropriação do poder político, o poder organizado sob sua forma estatal. Embora a teoria (ou ciência) política não possa ser reduzida a uma teoria do Estado, para o marxismo, sem a segunda, não há a primeira.

Mais problemática é, entretanto, a segunda identidade, aquela que iguala uma teoria marxista (ou socialista) do Estado a uma "teoria do Estado socialista ou da democracia socialista”. É sabido que Marx e Engels não desenvolveram de modo sistemático a pesquisa sobre essa teoria. O filósofo italiano tem razão. Eles não foram além de algumas páginas - são poucas -, presentes principalmente em A ideologia alemã, na Crítica ao Programa de Gotha e em A Guerra Civil na França. Mas o marxismo não se esgotou com Marx. A essas páginas seria importante acrescentar, principalmente, o extenso debate sobre o processo de transição na União Soviética e a crise desse processo. A esse respeito, a contribuição dos bolcheviques, primeiro, e do marxismo anti-stalinista, depois, torna-se incontornável em qualquer discussão livre de preconceitos ${ }^{1}$. Bobbio pode, pois, protestar a respeito do desenvolvimento desigual da pesquisa marxista sobre o Estado socialista, e o faz

\footnotetext{
${ }^{1}$ Particularmente importantes são os escritos de Leon Trotsky. É de se notar, entretanto, sua ausência em toda a discussão. "O longo silêncio" a respeito de Trotsky, como afirmou Antonella Marazzi, "explica-se historicamente com a ausência na Itália de uma tradição significativa de luta política e cultural em contraposição ao stalinismo" (1980:II). O silêncio chega às raias do absurdo quando em texto que precede o debate, Bobbio escreveu: "Os teóricos do marxismo têm sido muito hábeis na crítica à teoria das elites e à sua aplicação aos Estados capitalistas ). [...] mas não foram tão solícitos em promover estudos sobre o fenômeno (ou a ausência do fenômeno) nos Estados socialistas" (Bobbio. 1976a: 6). O filósofo italiano escrevia isso quase quarenta anos após a publicação por Leon Trotsky de A revolução traída! Bobbio dizia estremecer quando Cerroni chamava Wright Mills de "grande sociólogo" e a Max Weber de "“atento estudioso da burocracia", "uma falta, visível a olho nu, de senso das proporções e um testemunho de um juízo preconcebido" (Bobbio. 1975: 29). Mas o que dizer de sua afirmação de que a única análise das elites dos países socialistas teria sido feita por Milovan Djillas (Bobbio. 1976a: 6)? Ausência de senso das proporções? Idéias preconcebidas? Ou puro desconhecimento, como afirma Marazzi?
} 
em grande medida devido a um conhecimento parcial e insuficiente da teoria marxista do século XX, mas não pode reduzir a teoria marxista da política a uma teoria da transição.

A relação entre socialismo e democracia era, na verdade, o fulcro da questão e o artigo questionando a existência de uma teoria do Estado em Marx não fazia senão preparar o terreno, definindo as regras do debate por meio das equivalências acima apontadas. No número seguinte da revista Mondoperaio, Bobbio atacaria a questão com um novo artigo intitulado "Quali alternative alla democrazia rappresentativa?". Segundo o filósofo italiano, todos os que queriam que "o socialismo se efetivasse por meio da democracia e uma vez efetivado governe democraticamente" concordariam em atribuir à democracia um significado preponderante: "Este significado preponderante é aquele segundo o qual por 'democracia' se entende um conjunto de regras (as consideradas regras do jogo) que consentem a mais ampla e a mais segura participação à maior parte dos cidadãos, seja de forma direta, seja de forma indireta, nas decisões políticas" (Bobbio, 1975a: 40).

Essa definição minimalista era desdobrada a seguir em um conjunto de procedimentos que caracterizariam o que denominava "democracia representativa": voto universal e igual; liberdade de opinião e de organização; liberdade de escolha; vigência do princípio da maioria nos processos deliberativos; e garantia dos direitos das minorias, dentre eles, o de se tornarem maioria. Bobbio reconhecia que esse significado era restrito e que, enfatizando as regras, ou seja, os procedimentos, a definição não dizia respeito aos fins da democracia, e sim a meios considerados como desejáveis ${ }^{2}$. A seleção

\footnotetext{
${ }^{2}$ Um tratamento mais extenso da questão encontra-se em Bobbio (1984). É de se notar, entretanto, que no texto de 1984 o autor não inclui o voto universal como pressuposto da democracia, e sim a participação no processo decisório (direta ou indiretamente) de "um número muito elevado de membros do grupo" e restringe a regra da maioria para aqueles que participam do processo decisório (1984: 5). É pertinente a crítica de Losurdo a essa limitação da democracia: "Nessa base, não é mais possível distinguir entre democracia e uma oligarquia capaz de se autoperpetuar, respeitando no seu interior as regras do jogo" (Losurdo, 2003: 275).
} 
dos procedimentos indicados tinha não apenas um caráter descritivo como também normativo. Era a democracia liberal, pois é disso que se tratava, definida como a democracia sans phrase, o regime político que todo amante da liberdade individual e inimigo do despotismo deveria desejar.

Não é exagero afirmar que, para Bobbio, democracia era sinônimo de democracia liberal. O próprio filósofo italiano deixou isso sempre muito claro, afirmando a existência de um único tipo efetivo de democracia: aquela que se baseava nos princípios do liberalismo. Em seu conhecido ensaio "Della liberta dei moderni comparata a quella dei posteri", escrito em 1954 em resposta a um artigo de Galvano Della Volpe, afirmava: "quando falo de democracia liberal falo daquela que é para mim a única forma de democracia efetiva, enquanto democracia sem outra qualificação, principalmente se entendermos 'democracia não-liberal', indica, a meu ver, uma forma de democracia aparente" (Bobbio, 1955: 178).

Sem limitação do poder estatal e divisão (separação) de suas funções legislativa, executiva e judiciária não haveria liberdade, escrevia Bobbio em 1954. Mas na polêmica de 1975-1976 com os intelectuais do PCI, o filósofo italiano ia além. A construção de um conceito minimalista e procedimental de democracia permitia construir artificialmente um paradoxo: sem democracia, não haveria socialismo, mas com socialismo, não haveria democracia (1976a: 18). O paradoxo só poderia encontrar solução no interior do sistema filosófico bobbiano por meio da exclusão do socialismo do horizonte utópico. O socialismo não seria apenas improvável, ele também seria indesejável. O destino político da União Soviética e dos países do Leste europeu fornecia o álibi para tal:

“é necessário abordar também em profundidade o problema de porque onde foi realizado o socialismo não há democracia (pelo menos no sentido em que o conceito de democracia é claro e não se presta a equívocos) 
e onde são observadas as regras do jogo democrático o socialismo até hoje não ocorreu e não parece ser iminente (a julgar pelos países que, de fato, têm a democracia há mais tempo que nós)" (Bobbio, 1975a: 44).

O álibi, porém, lhe permitiria não apenas rejeitar o socialismo como também atribuir ao marxismo as razões da rejeição. A subvalorização do problema da democracia poderia ocultar uma aversão à democracia por parte dos socialistas. Para Bobbio, a incompatibilidade entre socialismo e democracia deveria ser creditada ao fato de o marxismo ter dirigido sua atenção aos problemas da revolução social e subestimado a necessidade de construir um modelo de forma estatal diversa, um modelo "democrático e socialista".

Esse modelo não poderia ter como pressuposto a democracia direta, segundo Bobbio. Seja na sua forma plebiscitária, seja na forma assembleísta (rousseauniana) ela não seria alternativa tecnicamente viável para a administração de grandes comunidades políticas. Do mesmo modo, as propostas do guild socialism e dos "sovietistas" não seriam alternativa ao Estado parlamentar clássico. Elas proporiam um alargamento do controle democrático do sistema político para o sistema econômico, mas ignorariam que há direitos dos cidadãos que não poderiam ser reduzidos a direitos dos produtores.

Por fim, o modelo político dos "países socialistas" não seria aceitável para o filósofo italiano. Uma ditadura socializante não seria uma alternativa. Para os pensadores antigos e modernos (Rousseau, Babeuf e Buonarroti, inclusive), a ditadura revolucionária seria sempre um governo excepcional e provisório. Com Marx, Engels e Lenin, o conceito assumiria novo significado. No sentido de ditadura de classe, seria sinônimo de domínio e, portanto, não diria respeito a uma forma provisória, mas, sim, a uma condição permanente da sociedade política. Afirmava Bobbio que essa defi- 
nição se assemelharia à definição clássica de governo despótico. Tal afirmação colocava-se, entretanto, em contradição com a teoria marxista do fim da política, antes apontada pelo mesmo autor como uma das causas da inexistência de uma teoria marxista do Estado. Pois, se o Estado socialista é um fenômeno transitório, rapidamente superado pelo fim da própria política, a ditadura do proletariado também seria transitória e rapidamente superada, e não permanente como afirmado.

Como indicaram de modo correto Pietro Ingrao e Franco Ferraroti durante o debate, as alternativas haviam sido artificialmente limitadas a duas: ou a democracia burguesa ou o despotismo stalinista (Ingrao, 1976: 7, e Ferraroti, 1976: 3). A escolha de Bobbio é evidente:

"A constituição republicana, com todos os seus defeitos de elaboração e com toda a lentidão na atuação é sempre, se comprada à esmagadora maioria dos regimes nos quais não existe uma constituição democrática ou não se tem notícia de uma constituição ampliada, uma trincheira avançada da qual não podemos recuar" (Bobbio, 1975a: 45).

O que as alternativas à democracia liberal acima desenhadas teriam em comum seria uma ignorância a respeito da especificidade da política e da necessidade da emancipação política para uma efetiva emancipação humana. Para Bobbio, no entanto, essa emancipação não implicava a superação da ordem política da democracia liberal e sim sua reafirmação. Fiel ao método croceano, cuja dialética se processava sem a negação da tese, Bobbio advogava uma emancipação que exigiria apenas reforçar as instituições políticas do presente, "emancipação esta que requer o desenvolvimento, a extensão, o reforço de todas as instituições das quais nasceu a democracia moderna e sua própria, mesmo que momentânea, suspensão não produz 
nenhuma vantagem”, concluía (Bobbio, 1975a: 48). A solução da relação entre democracia e socialismo seria assim a autolimitação dos marxistas ao horizonte da democracia liberal.

\section{Teoria política do reformismo}

A intervenção de Bobbio em Mondoperaio tinha um alvo claro: o Partido Comunista Italiano (PCI) e seus intelectuais. Não era a primeira vez que o filósofo italiano entabulava esse tipo de discussão com os intelectuais do PCI. Em 1954, ele já havia estabelecido os termos de um debate bastante similar sobre a democracia, liberdade e ditadura, em uma série de artigos depois reunidos em Politica e cultura ${ }^{3}$, motivando as respostas de Galvano Della Volpe (1954), já citada, e de Palmiro Togliatti, que assinava com o pseudônimo de Roderigo di Castiglia (1954 e 1955). Muito embora nesse primeiro debate Bobbio denunciasse a existência de uma ditadura no sentido estrito do termo na União Soviética, seu propósito imediato não era a reforma política desse país e sim garantir o compromisso do PCI com o regime liberaldemocrático italiano:

"A julgar pelo empenho com o qual o Partido Comunista Italiano defende das freqüentes violações, injustiças e ataques nossa atual Constituição que instituiu um governo democrático e parlamentar sobre bases liberais, pode-se formular a esperança de que isso seja decorrência não apenas, como dizem os adversários, de conveniência política, mas também de uma maior compreensão da validade funcional e da dimensão histórica deste tipo de regime" (Bobbio, 1954: 156).

\footnotetext{
$\overline{{ }^{3} \text { Trata-se dos artigos publicados originalmente em Nuovi Argomenti: "Democrazia e }}$ dittatura"; "Della libertá dei moderni comparata a quella dei posteri"; e "Libertà e potere" (Bobbio, 1955: 148-159, 160-194 e 269-282). 
Bobbio expunha a contradição existente na política do PCI que afirmava seu compromisso com as instituições liberal-democráticas na Itália, ao mesmo tempo em que apoiava completamente os procedimentos ditatoriais do governo soviético. As intervenções de Della Volpe e Togliatti não deixam de ser surpreendentes se comparadas com o debate dos anos 1970, pois elas tentavam, justamente, defender esse duplo compromisso. E são mais surpreendentes porque, ao fazer isso, afirmam que a União Soviética era, em 1954, expressão de uma democracia socialista, sustentando seus argumentos em ninguém mais, ninguém menos que o jurista russo Andrei Ianuarévitch Vichinski, o tristemente célebre procurador da farsa judicial dos Processos de Moscou.

O contexto de 1975 era, entretanto, outro. Não apenas porque a maioria do PCI já não se sentia obrigada a apoiar completamente a União Soviética, como também porque seu compromisso com a democracia-liberal havia se tornado muito mais intenso. Nesse então, em uma conjuntura marcada pelo crescimento eleitoral do PCI, tratava-se de definir até onde poderia ir esse compromisso do partido com as instituições da democracia liberal ${ }^{4}$. A publicação em Rinascita, o jornal do PCI, de uma resposta ao artigo de Mondoperaio, assinada por Umberto Cerroni, deu início a um debate que ocupou centenas de páginas em revistas e jornais italianos, mobilizando algumas dezenas de autores entre 1975 e 1976. O artigo de Cerroni não se opunha, entretanto, aos argumentos centrais de Bobbio. O próprio título do artigo "Esiste una scienza politica marxista?" e a resposta negativa à pergunta já indicavam a afinidade entre ambos.

Essa primeira afinidade não era de se estranhar, uma vez que Bobbio iniciava seu artigo questionando a existên-

\footnotetext{
$\overline{{ }^{4} \text { Nas eleições de 1976, o PCI alcançou o índice de 34,4\% dos votos, tornando-se o }}$ maior partido comunista do Ocidente. Para um paralelo entre o debate de 19541955 e o de 1975-1976 ver Rescigno(1976).
} 
cia de uma teoria marxista do Estado e citando as dúvidas que o próprio Cerroni levantava a respeito. Entretanto, outra afinidade, esta mais substancial, constitui-se. Embora Cerroni abordasse o problema aberto pela sua interrogação de modo diferente daquele de Bobbio, partilhava com este uma valoração positiva dos princípios da democracia liberal:

"é necessário afirmar que o socialismo tem o que receber do liberalismo, pelo menos por tudo o que diz respeito - na longa fase de transição - à sistemática político-jurídica da liberdade individual, garantia última da essencialidade do pluralismo político em uma sociedade evoluída" (Cerroni, 1975: 23).

O tom e o conteúdo do debate em Mondoperaio e Rinascita foram definidos por esses primeiros artigos. Teve início, assim, o que Guastini qualificou de uma "fatigante pantomima (na qual são, às vezes, mestres os intelectuais do PCI), de conceder o quanto se puder ao adversário, de mostrar-se o quanto for possível unânime, de ocultar o dissenso atrás de consensos táticos a meias" (Guastini, 1975: 186) ${ }^{5}$. Não é de se estranhar, portanto, que, ao longo da discussão, o próprio Bobbio seja criticado a destra nas páginas do Rinascita por Massimo Boffa (1975), que advogava uma pesquisa teórica marxista que não tivesse como meio o retorno a Marx, responsável, segundo afirmava, por soluções políticas de tendência totalitária. Também não é de se estranhar que Valentino Gerratana (1976) considerasse apropriado repreender Boffa por não ter interpretado de modo adequado a defesa que Bobbio teria feito do marxismo.

\footnotetext{
${ }^{5}$ Cafagna em sua fina análise das razões que levaram os intelectuais do PCI ao debate também utiliza o adjetivo fatigante para qualificar o debate: "A cautela, portanto, é um procedimento um pouco fatigante, comprometido, dominam todas estas intervenções, constringidas a se moverem em um espaço incômodo e estreito" (1976: 3).
} 
Para compreender esse debate extremamente complexo e sofisticado, torna-se necessário partir do pressuposto de que esses intelectuais estão engajados em um combate teórico contra adversários declarados e não declarados em uma cena histórica determinada. É necessário, também, compreender o modo de operação desses intelectuais, a liturgia que lhes é própria e a opção política que essa liturgia revela e esconde ao mesmo tempo. Daí a importância de tratar o debate em seu conjunto, resgatando para tal tanto os textos publicados em Mondoperaio e Rinascita, quanto às vozes dissonantes que apareceram em outras publicações ${ }^{6}$.

Não é possível, portanto, discutir de modo adequado a pergunta inicial - "Esiste uma dottrina marxista dello Stato?" - e a resposta por seu autor dada sem compreender que ela tinha por finalidade preparar o terreno para uma questão de caráter estratégico expressa na segunda interrogação: "Quali alternative alla democrazia rappresentativa?" Este segundo desafio lançado tornava-se inteligível quando inserido na cena histórica italiana. É notável no texto de Bobbio a temperatura política ainda elevada do autunno caldo e sua irritação para com o movimento estudantil e a extrema-esquerda. O impulso revolucionário já estava ficando para trás, mas não estava suficientemente distante para tranqüilizar um liberal moderado. Para o PCI e seus intelectuais, tratava-se de tomar distância desse impulso e afirmar pela enésima vez sua adesão às regras da democracia liberal inscritas em seu programa, no "compromisso histórico" com a democracia-cristã e nos artigos e discursos de Enrico Berlinguer que preparavam o caminho para o advento do chamado eurocomunismo.

\footnotetext{
${ }^{6}$ É revelador das opções políticas ocultadas pela liturgia que a revista Mondoperaio tenha reunido os textos publicados nela e em Rinascita em uma coletânea, mas tenha excluído os textos críticos publicados, em Critica del Diritto, Aut-Aut e outras. As regras do jogo democrático não valeram nessa ocasião.
} 
Giuseppe Vacca colocava as coisas (infelizmente) em seu lugar, quando afirmava o consenso que existiria na esquerda com as teses do filósofo italiano, "excluindo setores extremistas negligenciáveis" (Vacca, 1976: 64) ${ }^{7}$. O consenso ia além do explicitado por Bobbio e chegava até mesmo à Constituição italiana e à possibilidade de uma transformação socialista de acordo com as regras do jogo previstas pela legislação vigente. Segundo Vacca, havia "um concordante reconhecimento da boa qualidade do sistema democrático previsto na Constituição e a convicção de sua substancial adequação à transformação socialista em nosso país" (Vacca, 1976).

Mas ao invés de servir à transformação socialista, a "boa qualidade" da Constituição italiana forneceu o marco legal para a sistemática violação dos direitos civis e a prisão de, pelo menos, um dos participantes desse debate, Antonio Negri. A execrável aventura terrorista das Brigate Rosse permitiu ao governo italiano lançar uma ofensiva contra organizações de esquerda e movimentos sociais que contou com a anuência do PCI. Entre 1977 e 1980, o partido dirigido por Enrico Berlinguer apoiou a aprovação de leis que permitiam a interrogação de suspeitos sem a presença de advogado; a captura sem evidências de delito; e a detenção por 48 horas sem acusação formal, além da prisão por mais de dez anos sem julgamento (cf. Abse, 1985: 32, e Schimel, 1998).

\footnotetext{
${ }^{7}$ No mesmo sentido, mas sem a mesma fleuma, Ulisse reclamava do "transtorno dos super-revolucionários vociferantes e certas exaltações parlamentares de grupos de jovens" que não compreenderiam o valor da democracia "ajudando aqueles que se deseja abater" (1976: 25). Atacando sem nomear os "grupos de jovens", Ulisse fazia um amálgama entre o terrorismo das Brigate Rosse, uma organização militarista desvinculada dos movimentos sociais e, até mesmo, hostil a estes, e grupos que possuíam importante presença nos meios estudantis e operários e rejeitavam tanto os métodos dos brigadisti, como a política do PCI. Sobre os movimentos sociais e as organizações de esquerda do período ver Ginsborg (1998, Parte Prima, cap. IX e X) e Abse (1985); um tratamento mais detalhado pode ser encontrado em Balestrini e Moroni (2005).
} 
O processo judicial contra Negri nessas circunstâncias ganhou ares de farsa judicial. Preso juntamente com outros membros de Autonomia operaia no dia 7 de abril de 1979 e acusado infundadamente pelo procurador Pietro Calogero, simpatizante do PCI, de ser o dirigente intelectual e político das Brigate Rosse e de ter planejado e participado do seqüestro e assassinato do líder da Democrazia Cristiana Aldo Moro, Negri permaneceu longo tempo na cadeia aguardando um processo no qual as principais acusações tiveram de ser retiradas devido à ausência de quaisquer evidências (cf. Abse, 1985: 32-33). A respeito do acontecido, Michel Foucault disparava em sua conhecida entrevista anônima ao jornal Le Monde, em abril de 1980: "é verdade, não estamos em um regime no qual os intelectuais são enviados aos arrozais; mas, na realidade, diga-me, por acaso ouviu falar de um certo Toni Negri? Por acaso ele não está na prisão enquanto intelectual?” (1994: 105). O historiador Paul Ginsborg evidenciou a contradição da política do PCI nesse período:

"Aqui Berlinguer cometeu um de seus erros mais graves. Nos trinta anos de vida da República, os ativistas do PCI foram sempre alvos das medidas repressivas da polícia; porém, de 1976 em diante o partido tornou-se o mais zeloso defensor das tradicionais medidas de leis e ordens, ao invés de estar à frente das campanhas pelos direitos civis" (1998: 454).

Aqui sim, depois dos anos de chumbo e da perseguição policial e judicial indiscriminada aos estremisti na Itália, caberia falar das duras réplicas da história.

\section{Teoria marxista sem teoria da revolução?}

Esmiuçado o debate, revelam-se suas determinações. Colletti havia feito antes provocação semelhante, mas com um impacto muito menor. Cafagna aponta três razões para a 
diferente acolhida. Primeiro, Bobbio teria colocado na pauta um tema que os intelectuais do PCI estariam propensos a discutir, mas que, por razões diplomáticas, preferiam fazê-lo a partir de uma provocação externa e não interna ao marxismo (como era Colletti). Segundo, a distância que o filósofo italiano manteria do marxismo criava uma situação cômoda para esses intelectuais, que responderiam como representantes dessa tradição. E, por último, tendo publicado seu ensaio na revista oficial do Partido Socialista Italiano (PSI), o debate era, também, uma oportunidade política de aproximação deste (Cafagna, 1976: 2) ${ }^{8}$.

Os intelectuais do PCI estavam desse modo livres para apresentar suas idéias como se fossem expressão da teoria marxista, quando não do próprio Marx. Em sua maioria, ignoraram o questionamento à existência de uma teoria marxista do Estado ou o trataram de modo secundário e ritualístico ${ }^{9}$, preferindo discutir aquilo que para eles era relevante: a relação entre democracia e socialismo. O próprio Bobbio confessou-se surpreso com essa opção (Bobbio, 1976a: 66). Ela expressava a nova situação política italiana e o lugar que o PCI almejava ocupar nela. Que o debate tivesse adquirido a dimensão e o rumo que adquiriu não desagradava ao filosofo italiano. A recusa de uma teoria marxista da política (afinal, sem teoria do Estado não há teoria marxista da política) não era motivada pela constatação de uma incapacidade do marxismo se constituir em uma filosofia política, projetando utopicamente a república

\footnotetext{
${ }^{8} \mathrm{O}$ objetivo principal do PCI não era, entretanto, a aproximação com o PSI, como evidenciou Abse e sim a constituição de uma aliança com a Democrazia Cristiana (DC). Segundo Abse: "Confrontado com a emergência de novos movimentos sociais e a exaustão da centro-esquerda, ele [o PCI] optou por abandonar a tentativa da reconstruir a aliança com o PSI e optou, ao invés, por cortejar a própria DC" (1985: 21).

${ }^{9}$ A exceção é Vacca (1976 e 1976a). Fora das páginas de Rinascitá, Viola (1976) e Cermignani (1976).
} 
socialista ${ }^{10}$. Repetidas vezes Marx recusou-se a desenhar o futuro comunista e Bobbio sabia disso. E é porque sabia isso que insistia, fazendo jus a seu assumido empirismo, a respeito da necessidade de discutir a relação entre democracia e socialismo com base na análise da "realidade presente, tanto aquela dos Estados capitalistas quanto a dos Estados coletivistas" (Bobbio, 1975: 26). O debate real era sobre a política italiana e, particularmente, do PCI.

Encontra-se, pois, equivocado Atilio Boron quando, em um livro com algumas instigantes indicações para a pesquisa em teoria política publicado há poucos anos, revisita o debate com Bobbio unicamente a partir da primeira intervenção deste. Ao fazer isso, empenha-se em afirmar a existência de uma filosofia política marxista entendida como uma tentativa de "projetar o pensamento em busca da boa sociedade, ou de desenhar os contornos de uma nobre utopia" (Boron, 2003: 107). Mas nesse empreendimento, Boron, movido pelo louvável desejo de combater a "capitulação do pensamento crítico e a legitimação do capitalismo neoliberal", deixa de lado a teoria da revolução, justamente aquilo que era negado por Bobbio e pela maioria dos intelectuais do PCI naquele debate.

Se quisermos permanecer no campo do marxismo, a provocação de Guiducci faz sentido. A intervenção de Bobbio seria "uma ampla e como sempre aguda resposta a uma falsa questão no interior da teoria marxista". Para Guiducci, a pergunta correta seria: "Existe una teoria marxista dell'estinzione dello Stato?” (1975: 40). Guiducci procurava uma resposta a sua questão, aceitando a armadilha construída por Bobbio, e procurava imaginar o inimaginável: as formas insti-

\footnotetext{
${ }^{10}$ Utilizamos a expressão filosofia política no sentido de uma "descrição, projeção, teorização da ótima república, ou, se quisermos, como a construção de um modelo ideal de Estado, fundado sobre alguns postulados éticos últimos" (Bobbio, 2000: 67). Essa não é a única definição nem a mais aceitável para Bobbio.
} 
tucionais que sucederiam o Estado capitalista. Nessa busca, enfatizava a existência de sistemas capilares de autogestão, principalmente no setor terciário, nos quais ocorreria a produção de novas relações sociais e políticas ${ }^{11}$. Era a partir das situações históricas prefiguradas por esses sistemas que o autor em questão identificava a possibilidade de extinção do Estado (1975: 43).

Tanto a interrogação como a tentativa de resposta feita por Guiducci tinham seus méritos. A teoria marxista da política não pode ser resumida a uma teoria da extinção do Estado; mas se o objetivo é pensar o futuro e, no caso, a superação da política - e este é, a meu ver, o horizonte político de uma teoria marxista da política -, é preciso ter em mente que esse futuro só pode ser desenhado como superação do presente e que, portanto, é necessário fazer um levantamento das contradições existentes nesse presente que se quer superar. É esse o caminho seguido por Marx em sua crítica da economia política e o que lhe permite encontrar no interior do próprio processo de acumulação capitalista as tendências à socialização da produção, a negação dessas tendências pelo processo de apropriação privada que caracteriza o capitalismo e a negação da negação desse processo por meio da revolta "da classe trabalhadora, uma classe constantemente crescente em número e treinada, unida e organizada pelo próprio mecanismo do processo capitalista de produção" (Marx, 1990, v. 1: 929).

Essas contradições encontram-se no núcleo do próprio capitalismo e é com base no levantamento delas que o futuro desenhado por Marx se estabelece com as conquistas da era capitalista: "nomeadamente a cooperação e a posse em

\footnotetext{
${ }^{11}$ Guiducci (1975) ressalta as experiências dos setores de pesquisa, ensino, saúde, assistência, habitação, tempo livre e cultura e administração descentralizada, em que níveis elevados de eficiência são obtidos em sistemas não hierárquicos, capilares e autogestionários.
} 
comum da terra e dos meios de produção produzidos pelo próprio trabalho" (Marx, 1990, v. 1: 929). Não foi, entretanto, no coração do capitalismo, na produção de mercadorias e do processo de valorização do capital, que Guiducci procurou as tendências que poderiam prefigurar a "sociedade dos socialistas", e sim em sua periferia. Ao invés de uma contradição, ele encontrou uma diferença capaz de se ajustar mecanicamente àquilo que deveria ser negado e assumir um papel complementar no processo de acumulação do capital. Por essa razão que em sua construção utópica da "sociedade dos socialistas", Guiducci prescinde da negação da negação, ou seja, da própria revolução.

Não é possível, entretanto, pensar a extinção do Estado, como Guiducci pretendia, sem pensar a revolução. $\mathrm{O}$ silêncio em todo o debate sobre a revolução e a teoria da revolução em Marx é ensurdecedor. Todo o esforço teórico, levado a cabo pelos intelectuais que escreviam em Rinascita e Mondoperaio, para pensar o socialismo e a democracia é feito elidindo a necessidade da revolução socialista. Foi o próprio Bobbio quem deu início a essa elisão no debate, ao identificar duas regiões do pensamento político de Marx que mereceriam atenção.

Em primeiro lugar, escrevia Bobbio, Marx seria um autor realista, que despiria o Estado de seus atributos divinos ou éticos (como em Hegel) e o consideraria como organização de força, um aparelho coercitivo a serviço de uma classe dominante. "Marx é realista, condivide com os escritores realistas a idéia de que o Estado é o domínio da força. [...]. Que o Estado seja bom ou mau depende de quem tem as rédeas em mãos" (1975: 31). Em segundo lugar, para Marx o Estado serviria à realização de interesses que não são gerais, mas particulares. Com essa afirmação, estaria colocada em xeque a noção de que o Estado civil, superando o Estado natural, fosse a forma mais elevada de convivência racional entre os homens. 
Seriam essas as contribuições de Marx a uma teoria do Estado e da política e não aquelas contidas em seus escritos sobre a Comuna de Paris. Assim, muito embora Marx não tivesse escrito uma crítica da política comparável a sua crítica da economia, sua teoria política, afirma o filósofo italiano, "constitui uma etapa obrigatória na história da teoria do Estado moderno" (Bobbio, 1975: 31). Daí que ele concluísse, em conhecida entrevista ao jornal La Repubblica, que "non possiamo non dirci marxisti" (Bobbio, 1976b).

Certamente Bobbio tinha em mente duas (e outras tantas) conhecidas passagens do Manifesto comunista quando estabelecia aquelas que seriam as contribuições de Marx. Na primeira delas, afirmavam seus autores que "o governo moderno não é senão um comitê que gere os negócios comuns de toda a classe burguesa" (Marx, 1965: 163). Na segunda passagem, diziam que "o poder político, no sentido estrito do termo, é o poder organizado de uma classe para a opressão de outra" (Marx, 1965: 183). Ao definir o legado de Marx à teoria do Estado, o filósofo italiano evidenciava uma leitura reducionista dessas passagens, localizando essa contribuição na relação existente entre força e interesses: o Estado como aparelho coercitivo a serviço da realização de interesses particulares. Bobbio atribuiu desse modo a Marx "uma concepção instrumental do Estado" (Bobbio, 1975: 31) ${ }^{12}$.

Há entre a teoria instrumental do Estado e o reformismo uma afinidade teórica, muito embora ela não seja autoevidente. E é essa afinidade o que permitia elidir o momento da revolução no processo de transformação socialista. Em uma das intervenções de Bobbio no debate de 1954, essa afinidade encontra-se explicitada. Afirmava naquela ocasião o filósofo italiano que as instituições do Estado liberal-democrático não tinham senão um caráter instrumental, ${ }^{12}$ Para uma exposição das teorias instrumentalistas do Estado no interior do mar-
xismo, ver Gold, Lo e Wright (1975) 
constituindo um complexo de estratagemas e expedientes técnico-jurídicos que poderia ser utilizado "por quem quer que esteja de posse dos segredos de seu mecanismo" (Bobbio, 1955: 153). Perante esse complexo de estratagemas e expedientes não caberia perguntar, afirmava o filósofo italiano, se seu inventor era bom ou mau, amigo ou inimigo. $\mathrm{O}$ que importava era se seu funcionamento garantiria certos valores fundamentais, como a liberdade e a segurança e não se esse funcionamento beneficiaria determinadas classes sociais ou um modo de reprodução social determinado.

Quanto a essa questão, Bobbio, não tinha dúvidas: a forma do regime liberal-democrático representava, devido ao valor de sua técnica jurídica, a forma política mais refinada e mais progressiva existente. Daí considerasse importante que essas técnicas jurídicas não fossem concebidas como um fenômeno burguês, mas como um conjunto de normas que poderiam ser adotadas tanto pelos burgueses quanto pelos proletários com vista à defesa daqueles valores acima mencionados. No mesmo sentido apontava Furio Diaz, para quem era necessário atribuir "novos conteúdos àquilo que resta de válido das velhas fórmulas" da democracia representativa (Diaz, 1976: 88). Segundo Bobbio:

"Que esta máquina do Estado de direito nas mãos da burguesia funcione egregiamente para garantir a liberdade e a segurança aos burgueses e menos aos proletários é algo indiscutivelmente verdadeiro, mas isso não tira o valor da máquina, a qual, acima de tudo, não é responsável pelo modo como é operada. Esta máquina está longe de ser perfeita, mas a melhor maneira de aperfeiçoá-la não é, certamente, destruindo-a" (Bobbio, 1955: 155).

É verdade que algumas passagens dos textos de Marx e Engels, dentre elas as do Manifesto, foram lidas não poucas vezes como a expressão de uma concepção instrumental 
do Estado. Até mesmo Ralph Miliband afirmou que Marx e Engels "nunca abandonaram o ponto de vista de que em uma sociedade capitalista, o Estado era acima de tudo o instrumento coercitivo de uma classe dominante, ela própria definida em termos de sua propriedade e controle sobre os meios de produção" (Miliband, 1973: 7 - grifos meus). Entretanto, Marx e Engels fizeram referência ao Estado como um instrumento, máquina ou meio sempre de modo metafórico, complexificando a metáfora, a seguir, por meio da análise histórica concreta. O uso da metáfora do Estado como instrumento em A guerra civil na França ajuda a esclarecer a questão em um sentido oposto àquele de Bobbio. Não escolho discutir esse texto de modo ocasional. O faço porque ele permite, em primeiro lugar, discutir uma suposta concepção instrumental do Estado e, em segundo lugar, porque era esse o texto referido quando se falava "daquelas vinte páginas" que sustentariam o princípio de autoridade 58 (Bobbio, 1975).

Escrevia Marx naquele texto que em "presença da ameaça de uma sublevação do proletariado, a classe possuidora (classe possédente) unida utiliza nesse momento o poder de Estado sem consideração e com ostentação como a máquina de guerra nacional do capital contra o trabalho" (Marx, 1968: 61 - grifos meus). Chamo a atenção para o fato de Marx utilizar a metáfora do instrumento ("máquina”) para referirse tanto à função repressiva do Estado como a seu papel na manutenção das relações sociais capitalistas. E é por essa razão que cuidadosamente escreve capital e trabalho e não, simplesmente, capitalistas e trabalhadores, afastando, desse modo, a possibilidade de uma leitura reducionista que identificasse no Estado o instrumento direto e passivo de realização dos interesses imediatos de burgueses particulares.

Marx não reduzia a metáfora do instrumento a uma explicação do fundamento do poder político. Em suas análises históricas concretas a investigação sobre esse fun- 
damento é completada por uma pesquisa das formas e dos meios de realização desse poder ${ }^{13}$. A metáfora instrumental pode ser enriquecida se pensarmos a máquina estatal como aquilo que uma máquina é, segundo Marx, em O capital:

"toda máquina plenamente desenvolvida consiste em três diferentes partes essenciais: o motor, o mecanismo de transmissão e, finalmente, a ferramenta ou a máquina de trabalho. [...] Essas duas partes do conjunto do mecanismo [o motor e o mecanismo de transmissão] existem apenas para colocar em movimento a ferramenta de trabalho; usando esse movimento a ferramenta de trabalho toma o objeto do trabalho e o modifica como desejar" (Marx, 1990, v. 1: 494).

Como máquina de dominação, o Estado é dotado de ferramentas institucionais - "exército permanente, polícia, burocracia, clero e magistratura " - criadas "de acordo com um plano de divisão sistemática e hierárquica de trabalho" (Marx, 1968: 60). O processo histórico de constituição dessas ferramentas institucionais e os modos de realização da dominação de classe por meio delas são tema de $A$ guerra civil na França. Primeiro, escreve Marx, durante a monarquia absoluta, esse desenvolvimento encontrava-se entravado "por todo tipo de escombros medievais, prerrogativas senhoriais e de nobres, privilégios locais, monopólios municipais e corporativos e Constituições provinciais" (Marx, 1968: 60). Depois, com a Revolução Francesa de 1789, esses entraves foram destruídos e o governo foi subor-

\footnotetext{
${ }^{13}$ Não é admissível a idéia de que Marx e Engels, convencidos de que a esfera da política fosse aquela da força, tivessem se colocado apenas o problema do sujeito histórico dessa força "e não aquele dos diversos modos como essa força pode ser exercitada”, como afirma Viola (1976: 334). A guerra civil na França e O 18 Brumário de Luís Bonaparte são justamente uma análise dos meios de exercício do poder político.
} 
dinado ao parlamento, por meio do qual essa máquina capitalista ficou sob o controle direto das "classes possédantes", tornando-se, ao mesmo tempo, terreno do conflito entre as diferentes frações dessas classes (Marx, 1968: 61).

Entretanto, o controle direto pelas "classes possédantes" não era, ainda, o controle direto da burguesia. Marx descreveu, desse modo, o processo histórico no qual a burguesia assumiu o controle do aparelho de um Estado que já era capitalista. Esse processo era, por um lado, o desenvolvimento histórico do próprio modo de produção capitalista e do processo de subsunção do trabalho ao capital, e, por outro, o desenvolvimento histórico do antagonismo social. Assim, segundo Marx:

"À medida em que os progressos da indústria moderna desenvolviam, ampliavam e intensificavam o antagonismo de classe entre o capital e o trabalho, o poder do Estado assumiu cada vez mais a característica de um poder público organizado com a finalidade de escravização social, de um aparelho de dominação de uma classe" (Marx, 1968: 60 - grifos meus).

O antagonismo explicitado era, novamente, o que opunha "o capital e o trabalho". Tendo como fundamento o desenvolvimento desse antagonismo e da própria sociedade capitalista, o Estado pôde se constituir como um aparelho de dominação de "uma classe" específica, a burguesia, e não de qualquer classe. Mas foi apenas com a revolução de 1830 que ocorreu a transferência "do governo dos proprietários fundiários aos capitalistas” (Marx, 1968: 61). Após a Revolução de Junho de 1848, porém, essa burguesia foi obrigada a partilhar o poder com "todas as frações e facções rivais da classe dos apropriadores em seu antagonismo, agora abertamente declarado, contra as classes dos produtores" (Marx, 1968: 61). E finalmente, com o golpe de Luís Bonaparte e 
o Império, o Estado se colocava aparentemente acima da sociedade. Era esta "a única forma de governo possível, em uma época na qual a burguesia já havia perdido - e a classe operária ainda não havia adquirido - a capacidade de governar a nação" (Marx, 1968: 62).

Apesar de colocar-se acima da sociedade e de representar "os pequenos camponeses" (Cf. Marx, 1994: 532), o regime imperial na França era, segundo Marx, "a última forma do poder de Estado que a sociedade burguesa nascente havia criado como o meio de sua própria emancipação do feudalismo e que a sociedade burguesa chegando a seu pleno desenvolvimento finalmente transformou em um meio de subjugar o trabalho ao capital" (Marx, 1968: 62 - grifos meus). Um meio, uma máquina, que não era colocada em movimento, entretanto, diretamente pela burguesia e que muitas vezes o era contra ela, mas nem por isso suas ferramentas institucionais deixavam "de subjugar o trabalho ao capital". O que leva Marx a concluir que "a classe operária não pode se contentar em apossar-se do aparelho de Estado tal como se apresenta e de fazê-lo funcionar para seus próprios fins" (Marx, 1968: 59). Não bastava, portanto, mudar apenas o motor e o mecanismo de transmissão da máquina. Para que esta cumprisse outra função eram necessárias ferramentas novas.

A descrição feita por Marx do desenvolvimento histórico do Estado francês revelou que, sob um mesmo fundamento de classe, este pôde assumir uma multiplicidade de formas determinadas pela relação de forças entre as classes. Assim, embora certas passagens da obra de Marx e Engels tenham sido lidas de modo instrumental seu sentido mais forte aponta para outra direção. Em primeiro lugar, elas permitem pensar o Estado no processo de produção e reprodução do capital. Somente essa reprodução de relações sociais capitalistas, ou seja, da exploração do trabalho assalariado - a "escravização social" -, pode constituir o negócio comum 
de toda a burguesia. Em segundo lugar, permitem pensar os conflitos sociais no processo de produção e reprodução da dominação - "o antagonismo de classe entre o trabalho e o capital". O fundamento da teoria do Estado e da política de Marx pode ser encontrado, portanto, na articulação entre a reprodução política das relações sociais e a reprodução social das relações políticas.

Se esse é o fundamento do poder político, então não basta mudar "quem tem as rédeas em mãos", deixando intactas as relações entre domínio de classe e reprodução social. Marx e Engels insistem, no Manifesto comunista, na necessidade de uma revolução social que desse início a um período de transição no qual seriam destruídas as antigas relações de produção, de modo que fossem superadas as condições de existência dos antagonismos sociais, as próprias classes e, portanto, a dominação de classe, ou seja, a política. Com o desaparecimento dos antagonismos de classe "o poder público perderá seu caráter político" (Marx, 1965: 182). Afirmava Marx a esse respeito em seus artigos publicados no Vorwärts:

"A revolução como tal - a derrubada do poder estabelecido e a dissolução das antigas condições - é um ato político. $\mathrm{Ou}$, sem revolução o socialismo não pode tornar-se realidade. Este ato político é necessário na medida em que há a necessidade de destruir e de dissolver. Mas lá onde começa sua atividade organizativa, lá onde se manifesta seu próprio objetivo, sua alma, o socialismo rejeita seu envoltório político" (Marx, 1982: 418).

A revolução é, desse modo, o primeiro ato da extinção do Estado e, portanto, da negação da política. O programa do comunismo é, assim, um programa político da emancipação social. Ele se resume, segundo Marx, na: 
"declaração da revolução em permanência, a ditadura de classe do proletariado como ponto de transição para a abolição das diferenças de classes tout court, para a abolição de todas as relações de produção, para a derrubada de todas as idéias que nasceram dessas relações sociais” (Marx, 1994: 324).

A definição é dura e pode chocar espíritos dóceis. Essa era a intenção de Marx quando redigiu essa definição e a inscreveu em A luta de classes na França, estabelecendo por meio dela a distância que separava "o socialismo burguês”, que não pretendia, senão, derrubar a dominação da aristocracia financeira e libertar a indústria e o comércio dos entraves ao seu desenvolvimento, "do socialismo revolucionário”, que não pretendia, senão, a emancipação do proletariado. O respeito às regras do jogo era o que separava uns dos outros. É apenas por meio da revolução que os potenciais emancipatórios de uma democracia socialista presentes no interior do capitalismo poderiam se desenvolver. Onde podem ser encontrados esses potenciais? Eles só podem ser encontrados nas lutas que as classes subalternas levam a cabo no interior do capitalismo e contra ele. Se as tendências a um modo de produção pós-capitalista devem ser procuradas no interior do processo de produção capitalista, as tendências a uma política pós-capitalista devem ser procuradas na permanente revolta das classes subalternas dentro e fora desse processo.

A questão que movia Bobbio não dizia respeito, entretanto, à extinção do Estado, tema por ele considerado “ottocentesco per eccellenza” (Bobbio, 1975: 26). É possível, entretanto, questionar a legitimidade intelectual de tal procedimento que impõe ao marxismo uma problemática que lhe é alheia para logo a seguir fechar, sem argumento algum a não ser uma boutade, a única porta que lhe permitiria responder a questão no interior de sua própria problemática. De modo pertinente, Pompeo Farconi alertava que 
a extinção do Estado constituía dimensão imprescindível da doutrina de Marx, uma exigência da pesquisa realista sobre a realidade estatal (1976: 15).

É por meio dessa manobra argumentativa que Bobbio encaminha sua verdadeira questão: a teoria marxista pode acomodar em seu interior a defesa das regras e dos valores da democracia liberal? A recusa que o filósofo italiano promovia da teoria marxista do Estado encontrava-se amparada na impossibilidade de o socialismo assimilar as regras da democracia liberal como o horizonte político desejável e o que ele exigia dos socialistas e comunistas italianos era que fossem capazes de incorporar essas regras sob a forma de valores universais.

\section{Igualdade aparente e desigualdade real}

Embora Bobbio insistisse em afirmar uma concepção minimalista e procedimental de democracia, foi sobre valores, e 64 não sobre as regras do jogo, que boa parte do debate girou, como alertaram de modo apropriado Guastini (1975: 186) e Viola (1976: 324). A liberdade individual, a igualdade jurídica e a democracia parlamentar-representativa eram, para boa parte daqueles que ocuparam as páginas de Rinascita e Mondoperaio, valores universais que não eram em si demonstrados, mas simplesmente assumidos como pressupostos. $\mathrm{O}$ argumento que sustentava a universalização desses valores pode ser encontrado em Cerroni, que denunciava oposição entre liberdades formais e politicas e liberdades reais ou sociais, e, conseqüentemente, entre democracia política e democracia socialista.

Essa contraposição deveria ser creditada, segundo Cerroni, a um reducionismo economicista que, focado nas transformações na esfera da produção, teria como conseqüência um reducionismo político-programático. Esse reducionismo impediria de perceber que a democracia política seria uma conquista do movimento operário e 
socialista e que não faria sentido, portanto, a contraposição entre as formas de liberdade e de democracia acima enunciadas. No mesmo sentido, Occchetto afirmava "os valores permanentes [da democracia] e o próprio caráter de conquista e objetivo do movimento operário" (1976: 7), enquanto para Signorili, "a reconstrução da democracia é o dever histórico da classe operária na Itália, com formas e conteúdos tais a ponto de já representar a transição para a democracia socialista" (1976: 29). Essa continuidade entre democracia liberal e as formas políticas do socialismo era defendida por Cerroni, para quem a democracia socialista não seria senão a democracia política estendida. Sua conclusão é cristalina:

"na Itália a democracia política se defende e se expande graças ao movimento socialista; [...] o movimento socialista, em sua batalha anticapitalista, deve necessariamente desenvolver uma batalha antifascista e de promoção da democracia política. Mas isso significa, também, que se coloca a necessidade de substituir o capitalismo se se deseja fazer avançar a democracia e a possibilidade de fazer avançar o socialismo com a democracia” (Cerroni, 1975: 21).

Avançar o socialismo com a democracia significava a adesão dos socialistas àquelas regras do jogo definidas anteriormente, ou seja, a afirmação de uma via parlamentar ao socialismo. A operação teórica que permitiria àqueles que escreviam nas páginas de Rinascita e Mondoperaio a aproximação aos valores da democracia liberal era o esvaziamento dos fundamentos sociais da democracia e de socialismo. A qualificação do conceito de democracia por parte desses intelectuais dizia sempre respeito às modalidades desejadas de participação. A democracia era, assim, representativa (Bobbio, 1975a; Settembrini, 1975), direta (Guiducci, 1975), de massas (Ingrao, 1976), organizada (Vacca, 1976) ou mista 
(Ochetto, 1976). Mas pouco ou nada era dito a respeito de seu fundamento social. O conceito de socialismo, por sua vez, remetia aos fins desejados. O socialismo era, assim, justo, harmônico e racional (cf. Rescigno, 1976). Mas nada era dito do modo de produção que ele deveria caracterizar.

A contraposição que Bobbio fazia entre as formas representativas e diretas da participação lhe permitia colocar o debate em um terreno favorável. Era favorável porque o adjetivo "direta" que seguia o substantivo "democracia" permitia reduzir a discussão às modalidades de participação, contrapondo à democracia representativa uma alternativa que partilhava com esta um referencial individualista próprio do liberalismo, como alertou Antonio Negri (1976: 47), ao mesmo tempo em que, limitando a qualificação às modalidades de participação, afastava a necessidade de definir a fonte do poder político.

Sem essa definição, o que restava dos conceitos de democracia e socialismo eram valores aos quais os indivíduos poderiam aderir. Transformados em valores, esses conceitos deixavam de expressar realidades historicamente determinadas e passavam a cumprir a função de códigos de identificação de sujeitos políticos. Ser democrata ou socialista, o que para esses intelectuais era ou deveria ser a mesma coisa, significava, desse modo, partilhar certos valores universais: os valores da liberdade individual, protegidos pelos valores da igualdade jurídica. É o que explicitou, por exemplo, Ruffolo, ao afirmar que o ideal democrático se identificava com "três valores fundamentais: a igualdade, a liberdade e o autogoverno." Se estes valores são essenciais, continuava esse autor, e não são redutíveis à função da democracia, então "desaparece, pelo menos quanto aos fins, toda diferença entre democracia e socialismo" (Ruffolo, 1976: 69).

Ora, a determinação da democracia e do socialismo pelos valores que encerrariam é justamente a operação teórica denunciada por Marx e Engels em A ideologia 
alemã. Ao invés de considerar o liberalismo a partir dos interesses reais que determinaram seu surgimento, "os ideólogos alemães" do século XIX e os italianos do século XX transformavam seu conteúdo em "filosofia, em puras determinações conceituais", apresentando-se, assim "como pura exaltação, como pura ideologia sobre o liberalismo real" (Marx, 1982: 1.164).

Tais valores, não são, senão, aqueles que moviam a crítica marxiana da política desde os artigos publicados nos Deutsch-Französische Jahrbücher e cujo eco encontramos ao longo de suas obras da maturidade. São os valores que se consolidaram no século XIX em uma ideologia liberal que afirmava, ao mesmo tempo, a liberdade individual e a desigualdade social. A idéia de liberdade individual era, pelo menos desde Locke, ou seja, desde os primórdios do liberalismo, inseparável da idéia de propriedade privada, considerada como um direito natural equiparável ao direito à vida e à saúde ${ }^{14}$. O portador dessa liberdade era sempre um indivíduo proprietário que agiria de modo racional e independentemente dos demais.

Historicamente, essa liberdade do indivíduo (ou liberdade civil) assumiu a forma de um conceito negativo que a caracteriza como a ausência de impedimentos ou de coerção à ação do indivíduo. Já em Hobbes que, embora não possa ser identificado com a tradição liberal, contribuiu para a formulação desse conceito, encontramos a idéia de que por liberdade "é entendida, de acordo com a significação própria da palavra, a ausência de impedimentos externos" (Hobbes, 1981: 189). O usufruto pleno dessa condição

\footnotetext{
14 "O Estado de Natureza tem uma Lei de natureza para governá-lo, a qual obriga cada um: e a razão, a qual é essa lei, ensina a todos os que a consultem que, sendo todos iguais e independentes ninguém deverá prejudicar outro em sua Vida, Saúde, Liberdade ou Posses" (Locke. 1988, II, § 6: 271). Para Locke a propriedade consistia no direito à vida, à liberdade e aos bens (Locke, 1988, II, § 87: 323; § 123: 350; e $\$ 173$ : 383).
} 
ocorreria apenas em um Estado de natureza, enquanto na sociedade civil, esclarecia Hobbes, essa liberdade se encontraria restrita a todos os tipos de ações "permitidas pela lei" (Hobbes, 1981: 264). No mesmo sentido, afirmava Locke que a liberdade do homem em sociedade não poderia significar que cada um fizesse o que lhe aprouvesse: "Liberdade dos homens sob o Governo consiste em viver segundo uma regra permanente, comum a todos nessa sociedade e elaborada pelo Poder Legislativo nela erigido; uma Liberdade para seguir minha própria Vontade em todas as coisas nas quais a regra não prescreve; e não estar sujeito à vontade arbitrária de outro homem, inconstante, incerta e desconhecida” (Locke, 1988, § 22: 284).

Enquanto para Hobbes o poder de prescrever regras pertenceria de modo ilimitado e inalienável ao soberano, para Locke essa função caberia de modo limitado e intransferível ao poder legislativo, que deveria imprimir em suas leis um caráter universal, visando ao bem do povo e à preservação da propriedade. Aparece claramente em Locke, pois, a idéia de que o poder político não pode ameaçar a liberdade individual e que, ao fazê-lo, perderia seu próprio caráter de poder político: "Poder Absoluto Arbitrário, ou o governo sem leis estabelecidas e fixas nunca serão compatíveis com os fins da Sociedade e do Governo, pois os Homens não abandonariam a liberdade do estado de natureza para submeter-se senão para preservar suas vidas" (Locke, 1988, § 137: 359).

A idéia de que a liberdade individual deveria ser protegida das ameaças provenientes de um poder absoluto, seja ele o poder de um indivíduo seja o de uma coletividade, encontraria seu desenvolvimento no liberalismo pós-revolucionário do século XIX. A tirania da maioria havia se transformado no fantasma a ser esconjurado. Benjamin Constant, por exemplo, dirigia sua crítica à idéia de uma soberania popular ilimitada, capaz de ameaçar a própria liberdade. A concepção de um poder ilimitado dessa soberania estaria assen- 
tada no erro de considerar que a sociedade possuiria sobre seus membros um poder sem limites. Afirmava Constant em seus Principes de politique que existiria, entretanto, "uma parte da existência humana que, necessariamente, permanece individual e independente e que está, de direito, fora de toda competência social" (Constant, 1997: 312-313). Desse modo, "a soberania existe apenas de uma maneira limitada e relativa. No momento em que começa e independência e a existência individual, se interrompe a jurisdição dessa soberania" (Constant, 1997: 313).

$\mathrm{O}$ argumento era claramente anti-rousseauniano ou, pelo menos, contrário à leitura jacobina de Du contrat social, $\mathrm{e}$, nesse sentido, similar àquele desenvolvido posteriormente por Bobbio. A afirmação de que seria necessária "a alienação total de cada associado com todos os seus direitos a toda a comunidade" (Rousseau, 2004: 182) era para Constant intolerável. Igual oposição recebia a idéia hobbesiana de constituição de um poder por meio da transferência, por parte dos indivíduos, de "toda sua força e poder a um Homem, ou a uma Assembléia de homens, que possa reduzir suas diversas Vontades, por pluralidade de votos, a uma só Vontade" (Hobbes, 1985: 227). As atribuições do soberano não seriam nem absolutas nem arbitrárias para Constant:

"Os cidadãos possuem os direitos individuais independentes de toda autoridade social ou política, e toda autoridade que viola esses direitos torna-se ilegítima. Os direitos do cidadão são a liberdade individual, a liberdade religiosa, a liberdade de opinião, na qual está incluída sua publicidade, o desfrute da propriedade, a garantia contra todo ato arbitrário.

Nenhuma autoridade pode prejudicar esses direitos sem rasgar seu próprio título" (Constant, 1997: 317).

Merece destaque o lugar atribuído por Constant ao direito de propriedade. Para Constant, a propriedade não 
seria anterior à sociedade. Sem as garantias que apenas a associação poderia dar, o direito de propriedade seria o direito do primeiro ocupante, um direito da força, portanto. Mas propriedade seria condição da prosperidade da sociedade. O gozo de cada um dos membros da sociedade, garantido pela propriedade individual, faria com que a sociedade prosperasse. Sem a propriedade, escrevia Constant, "a espécie humana permaneceria estacionária e no grau mais bruto e selvagem de sua existência" (Constant, 1997: 443). E ecoando temas dos quais havia tomado conhecimento durante sua estadia em Edimburgo, concluía: "a abolição da propriedade seria destrutiva para a divisão do trabalho, base do aperfeiçoamento em todas as artes e ciências" (Constant, 1997: 443). Proteger a propriedade seria essencial porque significaria proteger a liberdade do proprietário: "esta liberdade é, com efeito, o fim de toda associação humana; sobre ela se apóia a moral pública e privada: sobre ela repousam os cálculos da indústria, sem ela não haveria nem paz, nem dignidade, nem felicidade para os homens" (Constant, 1997: 483).

Mas a liberdade à qual Constant fazia referência não era a liberdade política dos antigos, e sim a liberdade individual dos modernos. A distinção e separação que Constant realizava entre a liberdade dos antigos e aquela dos modernos era perfeitamente simétrica à que a Revolução Francesa de 1789 havia feito entre os direitos do citoyen e aqueles do Homme. Para Marx, em A questão judaica, esse homme não era senão o membro da sociedade civil burguesa. Seus direitos eram "os direitos do membro da sociedade civil, quer dizer, do homem egoísta, do homem separado do homem e da comunidade". Como membro da sociedade civil burguesa, sua condição humana era determinada pela sua condição de proprietário: "a aplicação prática do direito do homem à liberdade é o direito do homem à propriedade privada" (Marx, 1982: 366). 
Ao proclamar a propriedade um direito humano, a Revolução Francesa "atribuiu à propriedade privada uma aparência liberal” (Marx, 1982: 1.176). Mas o que é esse direito de propriedade? Não é senão "o direito de usufruir de sua fortuna e de dispor à son gré, sem se importar com o próximo, independentemente da sociedade". Que o indivíduo agindo como "mônada isolada e retraída sobre si própria" possa "dispor à son gré de acordo unicamente com seu interesse pessoal: este é o fundamento da sociedade civil burguesa" (Marx, 1982: 367). Em A ideologia alemã, Marx e Engels apontaram a dupla relação na qual se estabelece esse jus utendi e abutendi que normatiza a relação do indivíduo com sua propriedade (Marx, 1982: 1.110). Por um lado, esse direito expressa o fato de que propriedade privada se encontra completamente independente da comunidade, por outro, ele expressa a ilusão de que essa propriedade descansa exclusivamente sobre a vontade privada do indivíduo egoísta.

Este nexo ilusório estabelecido entre a propriedade privada e a vontade do indivíduo é o que permite que essa propriedade, por definição um objeto extracorpóreo, possa aparecer como parte constitutiva da esfera individual. Tratase, assim, de um indivíduo ampliado. Nenhum dos direitos individuais afirmados pela Déclaration des Droits de l'Homme et du Citoyen, de 26 de agosto de 1789, ou pela Constituição jacobina de 1793, ia além desse homem egoísta e ampliado que caracterizava a sociedade civil burguesa. A própria sociabilidade humana nasceria na sociedade civil e seria garantida exclusivamente pela "necessidade natural, o carecimento e o interesse privado, a conservação de sua propriedade e de sua pessoa egoísta" (Marx, 1982: 368) ${ }^{15}$. Se

${ }^{15}$ Adam Smith expôs esse princípio de modo clássico em A riqueza das nações: "Não é da benevolência do açougueiro, do cervejeiro ou do padeiro que esperamos nosso jantar, mas de sua consideração para com seu próprio interesse. Dirigimonos não à sua humanidade, mas à sua auto-estima, e nunca lhes falamos de nossas necessidades, mas de suas próprias vantagens" (Smith, 1981, v. I: 26. Ver, tb., sua metáfora da "mão invisível": 455-456). 
para Hobbes a sociedade política seria a garantia da vida em sociedade, para o liberalismo seria a ação dos indivíduos movidos por seus próprios interesses que a promoveria.

Para o liberalismo clássico, o bourgeois era a verdade do citoyen (Marx, 1982: 1.161). A liberdade estava, desse modo, vinculada à condição de proprietário, único em condição de exercê-la efetivamente. A liberdade pessoal "só existe para os indivíduos moldados pelas condições da classe dominante e para aqueles que pertencem a essa classe", afirmava Marx em A ideologia alemã (1982: 1.111-1.112). Constituída a partir dessa liberdade, a igualdade jurídica entre todos os indivíduos permitia a formação, apenas, de uma comunidade aparente na qual o homem era "o membro imaginário de uma soberania ilusória” por meio da qual uma classe exercia seu domínio sobre a outra (Marx, 1982: 257).

É na esfera da circulação de mercadorias, na qual os homens agem como simples indivíduos privados, que essa comunidade encontra seu suporte material. Nela todo indivíduo aparece como proprietário livre de, ao menos, uma mercadoria e disposto a trocá-la pelo seu equivalente, escrevia Marx em O capital (1990, v. I: 280). Trabalhador, proprietário de sua força de trabalho, e capitalista, proprietário dos meios de produção; camponês, proprietário do produto de seu próprio trabalho, e latifundiário, proprietário da terra; industrial, proprietário da fábrica, e banqueiro, proprietário do dinheiro; no mercado, eles não são diferentes. Todos se apresentam na esfera da circulação como iguais permutando entre si valores iguais. $\mathrm{O}$ contrato entre indivíduos livres e iguais perante a lei é a forma jurídica que assume esse ato.

Essa igualdade aparente se desfaz na esfera da produção de mercadorias. Nela a assimetria das relações sociais aparece de modo inequívoco. Não há mais iguais permutando entre si. O capitalista permanece proprietário de seus meios de produção, mas a força de trabalho do trabalhador, agora, também lhe pertence. Na esfera da circulação, a úni- 
ca autoridade conhecida é a da concorrência, a coação que exerce sobre os indivíduos isolados, a pressão de seus mútuos interesses. No regime capitalista de produção, a autoridade do capital é verdadeira condição de produção. "Que o capitalista possa comandar no terreno da produção é agora tão indispensável quanto o comando do general no campo de batalha" (Marx, 1990, v. I: 448). A forma dessa autoridade é "puramente despótica" (Marx, 1990: 450), revelando o antagonismo existente no próprio processo de produção e reprodução social.

Assim como é a produção de mercadorias que determina a circulação destas, no processo de reprodução, é a desigualdade social que determina a igualdade formal e a liberdade individual. A restrição da liberdade à esfera do indivíduo isolado pressupõe, portanto, a manutenção da assimetria e do antagonismo sociais que a fundam. E, por sua, vez, a manutenção dessa assimetria e desse antagonismo exige um indivíduo formalmente livre. A condição para que a ditadura de classe da burguesia "possa exercer-se por meio de uma igualdade formal de todos, inclusive dos proletários”, como afirma Cerroni (1976: 21), é que a divisão do trabalho e o despotismo fabril continuem existindo. Era justamente essa assimetria e esse antagonismo social, sob a qual se funda a liberdade individual, que Cerroni esquecia quando defendia que "a ditadura do proletariado seja exercida por meio da igualdade formal de todos, inclusive dos não-proletários e dos próprios burgueses" (1975: 21). Pois tal afirmação, conforme ressaltou Rescigno, só poderia significar que o proletariado, como classe dominante, deveria construir o socialismo preservando o direito de propriedade e o despotismo fabril (e é por isso que os burgueses continuariam sendo burgueses), bem como todos os direitos políticos da burguesia, inclusive o de utilizar seu poder econômico para tornar-se novamente dominante por meio das regras do jogo preconizadas por Bobbio (1976: 41). 
Ruffolo não estava muito aquém de Cerroni quando propunha como base para uma estratégia de transição, refutando "as rupturas históricas e miraculosas", uma gestão da "crise do capitalismo de uma maneira não capitalista, dirigindo-se para a uma sociedade socialista" por meio de um "compromisso histórico com o capitalismo nacional e internacional" que permitisse, por um lado, "as condições mínimas de produtividade do sistema capitalista" e, de outro, as condições para a "aquisição de uma forte base de consentimento popular". Para tal, concluía o autor, seria necessária "uma política de austeridade igualitária: uma rigorosa disciplina dos consumos e uma ampla redistribuição de rendas" (Ruffolo, 1976: 76-77). A missão histórica do socialismo era reduzida, assim, à superação capitalista da crise do capitalismo por meio da construção de sua base popular. Uma transição do capitalismo para o capitalismo.

Essa posição não era estranha ao próprio PCI. Em entrevista ao jornal Corriere della Sera, o líder comunista Giorgio Napolitano afirmava, na ocasião, que seu partido não pretendia repetir uma "experiência de estatização total" e que considerava importante "a) a sobrevivência da propriedade privada em certos setores; b) uma liberdade e competitividade de iniciativa seja pelas empresas públicas, seja pelas empresas privadas, no quadro de uma direção planificada da economia” (apud Ulisse, 1976: 25). Mas essa política não seria, para Napolitano, uma "estratégia de transição"; ela era a realização do próprio socialismo.

De modo extremado, a "transição" proposta por Ruffulo e o "socialismo" de Napolitano expressam o caráter ilusório do socialismo ao qual seria possível chegar mediante as regras do jogo. A condição para a realização da igualdade jurídica, ou seja, para a incorporação dos trabalhadores à esfera do direito e do Estado é que eles o façam como cidadãos despidos de sua condição de produtores, ou seja, que o façam como indivíduos atomizados, abandonando sua 
condição antagônica comum. A identidade real existente entre os indivíduos, aquela que faz deles membros de uma comunidade de produtores, dissolve-se em uma identidade aparente que faz deles cidadãos de uma comunidade de indivíduos. As regras do jogo preconizadas por Bobbio e aceitas por Cerroni não fazem senão limitar a participação política aos indivíduos isolados, aos cidadãos de uma comunidade ilusória. Uma participação que é cada vez menor e mais ineficaz, como alertou recentemente Losurdo (2004).

A superação da comunidade aparente e a realização de uma comunidade real, o comunismo, só podem ocorrer por meio da superação da igualdade aparente que se manifesta na esfera do mercado e da desigualdade real que se afirma na esfera da produção. A emancipação social tem início como emancipação política, mas a emancipação política só se realiza plenamente com a emancipação social. O fim da dominação capitalista só pode ocorrer com o fim do despotismo fabril e das relações sociais capitalistas. Era esta unidade dialética entre o político e o social que escapava a Bobbio.

\section{Conclusão}

Se repetíssemos a pergunta feita por Bobbio trinta anos atrás, mas tendo por alvo os participantes do debate, seria forçoso reconhecer que não possuíam uma teoria marxista da política e que se moviam livremente no campo teórico da democracia liberal. Ou seja, eram incapazes, em sua maioria, de construir uma teoria "diversa e antagonista com relação à teoria constitucionalista do Estado capitalista”, como apontava Negri na ocasião (1976: 35) ${ }^{16}$. O aparente consenso da maioria dos autores que escreviam nas páginas de Mondoperaio e Rinascita a respeito da "inexistência, ou insuficiência, ou deficiência, ou irrelevância" de uma teoria

${ }^{16}$ Justiça seja feita: a exceção, reconhecida até mesmo por Negri, era Pietro Ingrao (1976). 
marxista da política, como afirmava Bobbio, permitia que se afastassem da obra de Marx sem abrir mão da autoridade deste. O vazio criado pela suposta inexistência de uma teoria marxista da política era preenchido, assim, pela teoria liberal do Estado capitalista.

Protestando contra o uso escolástico e repetitivo dos textos de Marx, Bobbio havia criado o pretexto necessário para tal. Não seria de bom tom responder-lhe por meio de Marx. Nas páginas de Mondoperaio, Macchioro protestou na ocasião: "a filípica bobbiana contra os escolásticos e os repetidores procede sem dar nomes" (1976: 65). E com razão, porque a filípica bobbiana chegava tarde demais e condenava aquilo que estava sendo superado. Em sua pesquisa sobre o marxismo ocidental, Perry Anderson (2004) havia constado de modo consternado o lugar subalterno que a política ocupava na pesquisa marxista após a década de 1930. Os tempos, entretanto, eram outros. Poulantzas (1968) e Miliband (1969) haviam antecipado uma vigorosa retomada dos estudos marxistas críticos que superavam a condição subalterna da teoria política no programa de pesquisa marxista ${ }^{17}$. O marxismo acompanhava, assim, um movimento de renovação da própria teoria política - e não apenas daquela de inspiração marxista - que procurava respostas para a crise do final dos anos 1960 e início dos 1970 (cf. Ball, 2004).

Marx não desenvolveu de modo completo esse programa de pesquisa crítica da política. Ao contrário da crítica da economia política, que tem sua sede em $O$ capital, sua crítica da política é dispersa e fragmentada. Mas deixou claramente as indicações para o desenvolvimento dessa pesquisa em vários de seus escritos de juventude e, principalmente, no Manifesto comunista, em A luta de classes na França, em O 18 Brumário de Luís Bonaparte, em A guerra civil

\footnotetext{
${ }^{17}$ Tentativas de mapear esse esforço podem ser encontradas em Gold, Lo e Wright (1975 e 1976); Jessop (1982); Barrow (1993); e Carnoy (1984).
} 
na França, dentre outros textos, além, é claro, das passagens de $O$ capital nas quais discute a relação entre a política e o processo de acumulação capitalista. A renovação da teoria marxista da política a partir do final dos anos 1960 revelou que o estudo dessas obras ainda era insuficiente. Os limites do debate italiano, notadamente a incapacidade dos intelectuais do PCI de pensar uma teoria política antagônica à teoria constitucional-liberal, e, portanto, de desenvolver a própria teoria marxista que diziam representar, mostrava, por outro lado, que mais uma volta a Marx e aos clássicos do marxismo não seria tempo perdido.

Os acontecimentos do final do século XX e o início do XXI mandaram pelos ares certezas políticas e teóricas. E, se por um breve período de tempo foi celebrada a enésima morte de Marx, o vigor da tradição marxista no presente permite afirmar que as notícias sobre seu falecimento haviam sido algo exageradas. Uma nova situação política e um novo nexo teoria - movimento têm permitido um importante desenvolvimento do marxismo crítico, adogmático e antidogmático. É que nos momentos de crise o marxismo revela sua capacidade de constituir uma crítica da política que se afirma como o programa teórico da superação da teoria política de sua época e o programa prático da superação da própria política.

Para dar conta desses desafios, que são definidos não pelo marxismo, e sim postos pelo próprio processo histórico, o programa de pesquisa da teoria marxista da política deveria desenvolver-se de modo unitário sobre três eixos complementares: uma crítica da política e do Estado burguês, uma teoria da revolução e uma teoria da transição. Essa separação é meramente analítica e diz respeito a três momentos diferentes, mas articulados da realidade política: o Estado capitalista, a revolução socialista e as formas estatais da transição (dentre elas o Estado socialista). A teoria do Estado capitalista e a teoria do Estado socialista são 
diferentes desenvolvimentos de uma mesma teoria, a teoria marxista do Estado. Mantidas as condições sociais sobre as quais esse programa de pesquisa foi construído, ou seja, enquanto o poder mantiver sua forma política, enquanto ele for o poder de uma classe para a opressão de outra, essa teoria preservará sua capacidade crítica.

A crítica da política iniciada, mas não completada, por Marx, é, assim, uma crítica da teoria política liberal e uma explicação alternativa dos fundamentos e das formas do poder político. A oposição se estabelece, desse modo, entre a teoria marxista da política e a teoria liberal ou constitucionalista da política e não, como parece pretender Bobbio, entre a teoria do Estado socialista e da democracia socialista e a teoria do Estado burguês e da democracia burguesa. Ora, o Estado e a democracia socialistas são opostos ao Estado e à democracia burguesa e a teoria socialista (ou marxista) é oposta (ou deveria ser) à teoria burguesa. Mas dessas antíteses não se pode passar a uma cisão entre a teoria que permite pensar o Estado burguês e a teoria que tem por objeto o Estado socialista.

A diferenciação entre teoria do Estado capitalista e teoria do Estado socialista não faria sentido sequer no interior do argumento de Bobbio que procura, a todo o momento, preencher o suposto vazio de uma teoria das instituições socialistas com uma teoria das instituições democráticas válida tanto para o capitalismo como para o socialismo. Aqui, entretanto, revela-se uma diferença fundamental. Para o filósofo italiano, a unidade da teoria é definida por aquilo que ele quer afirmar, a permanência das regras do jogo, as formas institucionais da democracia contemporânea. Sua teoria é, assim, uma teoria positiva da política. Para o marxismo, a unidade da teoria é dada por aquilo que ele quer negar, o poder político. O marxismo é, assim, uma teoria negativa da política. É essa negatividade a condição para a existência de uma teoria marxista da política. 


\section{Alvaro Bianchi}

é professor do Departamento de Ciência Política da Universidade Estadual de Campinas (Unicamp) e coordenador do Grupo de Pesquisa Marxismo e Teoria Política do Centro de Estudos Marxistas (Cemarx)

\section{Referências bibliográficas}

(Os artigos que compõem o debate de 1975-1976 estão marcados com*.)

ABSE, Tobias. 1985. "Judging the PCI". New Left Review, n. 153, p. 5-40, sept./oct.

ANDERSON, Perry. Consideraçoes sobre o marxismo ocidental. Nas trilhas do materialismo histórico. São Paulo: Boitempo. 2004.

BALESTRINI, Nanni; MORONI, Primo. 2005. L'orda d'oro (1968-1977): la grande ondata rivoluzionaria e creativa, politica ed esistenziale. Milano: Feltrinelli.

BALL, Terence. 2004. "Aonde vai a teoria política?" Revista de Sociologia e Política, n. 23, p. 9-22, nov.

BARROW, Clyde W. 1993. Critical theories of the State: marxist, neo-marxist, postmarxist. Madison: University of Wisconsin.

BOBBIO, Norberto. 1955. Politica e cultura. Turim: Einaudi.

1975. Esiste una dottrina marxista dello Stato? Mondoperaio, a.

28, n. 8-9, p. 24-31, ago./set."

1975a. "Quali alternative alla democrazia rappresentativa?" Mondoperaio, n. 10, p. 40-48, ott."

1976. "Quale socialismo?" Mondoperaio, a. 29, n. 5, mag. 53-63."

.1976a. Quale socialismo? Discussione di un'alternativa. Turim:

Einaudi."

.1976b. "Perché non possiamo non dirci marxisti, intervista a cura di F. De Luca”. La Repubblica. 20 feb."

Turim: Einaudi.

1984. Il futuro della democrazia: una difesa delle regole del gioco.

. 2000. Teoria geral da política: a filosofia política e as lições dos clássicos. Rio de Janeiro: Campus.

BOFFA, Massimo. 1975. "Le dure repliche della storia. Ancora a proposito del saggio di Norberto Bobbio". Rinascita, n. 48, p. 23-24, 5 dic."

CAFAGNA, Luciano. 1976. "La fattoria delle 'anime morte". La Repubblica, p. 2, 20 gen.*

CARNOY, Martin. 1984. The state and political theory. Princeton: Princeton University. 
CASTIGLIA, Roderigo di [Palmiro Togliatti].1954. "Il tema di liberta". Rinascita. a. 11, n. 11-12, p. 733-736, nov.-dic. 1955. "Ancora sul tema della liberta”. Rinascita, a. 12, n. 7-8, p. 498-501, lug./ago.

CERMIGNANI, Bruno. 1976. "Anche Bobbio sbaglia nell'uso di Marx". Il Mondo, 18 mar. 15-17.*

CERRONI, Umberto. 1975. "Esiste una scienza politica marxista? Discutendo con Norberto Bobbio". Rinascita, n. 46, p. 21-23, 21 nov." . 1976. "Replica a Bobbio senza diplomazia. La polemica sul marxismo". Paese sera-libri, p. 1, 28 nov."

COLLETI, Lucio. 1974. "A political and philosophical interview". New Left Review, n. 86, p. 3-28, jul./aug.

CONSTANT, Benjamin. 1997. Écrits politiques. Paris: Gallimard.

DELLA VOLPE, Galvano. 1954. "Comunismo e democrazia moderna”. Nuovi Argomenti, n. 7, p. 131-142, mar.-apr.

DIAZ, Furio. 1976. "Teoria dello stato e volontà política”. Mondoperaio, a. 29, n. 1, p. 82-89, gen."

DRAPER, Hal. 1976-1986. Karl Marx's Theory of Revolution. New York: Monthly Review Press. 4v.

FERRARI, Vincenzo. 1977. "Socialismo e democrazia liberale. A proposito di alcuni recenti scritti di Norberto Bobbio". Sociologia del diritto, a. 4, n. 2, p. 458-464."

FERRAROTTI, Franco. 1976. "Marx usato contro Marx". Corriere della sera, p. 3, 3 mar. $^{*}$

FOUCAULT, Michel. 1994. "Le philosophe masqué". In: Dits et écrits 1954-1988: édition établie sous la direction de Daniel Defert et François Ewald avec la collaboration de Jacques Lagrange. Paris: Gallimard, v. IV, (1980-1988): 104-110.

G. D. 1975. "Il marxismo e lo stato moderno". Avanti!, 9 nov. 4."

GALEAZZI, Umberto. 1977. "La mancanza di una teoria marxista dello stato". Il Popolo, p. 3, 25 mar.*

GERRATANA, Valentino. 1976. "Quando la democrazia è sovversiva. Un intervento nella discussione sul saggio di Norberto Bobbio”. Rinascita, a. 33, n. 1, p. 29, 2 gen.

GINSBORG, Paul. 1998. Storia d'Italia. 1943-1996: famiglia, societa, stato. Torino: Einaudi.

GOLD, David A.; LO, Clarence Y. H.; WRIGHT, Erik Olin. 1975. "Recent developments in Marxist theories of the capitalist State". Monthly Review, v. 27, n. 5 , p. $29-43$.

1976. "Recent developments in Marxist theories of the capitalist State. Part 2". Monthly Review, v. 27, n. 6, p. 36-51. 
Alvaro Bianchi

GUASTINI, Riccardo. 1975. "Note intorno a un dibattito in corso: dittatura proletaria e democrazia rappresentativa”. Critica del diritto, a. 2, n. 5-6, p. 186-189, mag.-dic."

GUIDUCCI, Roberto. 1975. "La città dei cittadini e la società dei socialisti". Mondoperaio, a. 28, n. 12, p. 40-43, dic.*

HOBBES, Thomas. 1985. Leviathan. Edited with an introduction by C. B. Macpherson. Londres: Penguin.

INGRAO, Pietro. 1976. "Democrazia borghese o stalinismo? No: democrazia di massa. A proposito del saggio di Norberto Bobbio”. Rinascita, a. 33, n. 6, p. 7-9, 6 feb."

JESSOP, Bob. 1982. The capitalist State. Oxford: Martin Robertson.

LOCKE, John. 1988. Two tratises of government. Edited with an introduction and notes by Peter Laslett. Cambridge: Cambridge University.

LOSURDO, Domenico. 2004. Democracia ou bonapartismo: triunfo e decadência do sufrágio universal. Rio de Janeiro/São Paulo: UFRJ/Unesp.

MACCHIORO, Aurelio. 1976. "Socialismo e democrazia garantista". Mondoperaio, a. 29 , n. 4 , p. $65-68$. apr."

MARAZZI, Antonella. 1980. Trotsky in Italia: bibliografia sistematica. Roma: Controcorrente.

MARX, Karl. 1965. CEuvres. Économie. Edition établie, et a.tée par Maximilien Rubel. Paris: Gallimard. t. I.

1968. La guerre civile en France. Paris: Sociales.

.1982. Euvres. Philosophie. Edition établie, présentée et a.tée par Maximilien Rubel. Paris: Gallimard. t. III. 1990. Capital. Londres: Penguin. 3v.

1994. Euvres. Politique. Edition établie, présentée et a.tée par Maximilien Rubel. Paris: Gallimard. t. IV.

MILIBAND, Ralph. 1973. The State in capitalist society. Londres: Quartet.

NEGRI, Antonio. 1976. "Esiste una dottrina marxista dello stato?" Aut aut, n. 152-153, p. 35-50, mar.-giu."

OCCHETTO, Achille. 1976. "Sul concetto di 'democrazia mista'. Intervento nel dibattito suscitato dal saggio di Norberto Bobbio”. Rinascita, n. 2, p. 7-8, 9 gen."

POMPEO FARACOVI, Ornella. 1976. "Dunque, quale socialismo". Il Ponte, a. 32, n. 6, p. 612-619, 30 giu.*

POULANTZAS, Nicos. 1968. Pouvoir politique et classes socials. Paris: Maspero.

RESCIGNO, Ugo. 1976. "Democrazia borghese e democrazia proletaria. A proposito del dibattito fra Bobbio, Cerroni e altri”. Nuovo impegno, a. 12, n. 33 , p. $38-54$. 
RUFFOLO, Giorgio. 1976. "Eguaglianza e democrazia nel progetto socialista". Mondoperaio, a. 29, n. 4, p. 69-77, apr."

SCHIMEL, Anne. 1998. "Justice de 'plomb' em Italie”. Le Monde Diplomatique, p. 1, avr.

SETTEMBRINI, Domenico. 1975. "Socialismo marxista e socialismo liberale". Mondoperaio, a. 28, n. 12, p. 44-48, dic."

SIGNORILE, Claudio. 1976. "La democrazia che trasforma lo stato". Mondoperaio, a. 29, n. 3, mar. 26-29."

SMITH, Adam. 1981. An Inquiry into the Nature and Causes of the Wealth of Nations. Edited by R. H. Campbell e A. S. Skinner. Textual editor W. B. Tood. Indianapolis: Liberty Fund. 2v. (The Glasgow Edition of the Works and Correspondence of Adam Smith, v. II).

ULISSE. 1976. "Chi è rivoluzionario". Il Mondo, a. 28, n. 10, 25, p. 4 mar.* VACCA, Giuseppe. 1976. "Discorrendo di socialismo e di democrazia". Mondoperaio, a. 29, n. 1, p. 90-97, gen."

. 1976a. "Discorrendo di socialismo e democrazia (II)". Mondoperaio, a. 29 , n. 2 , p. 61-70, feb."

VIOLA, Francesco. 1977. "Il socialismo alla prova della democracia". Aquinas, a. 20. 319-344.*

VOLPE, Galvano Della. 1954. "Comunismo e democrazia moderna”. Nuovi Argomenti, n. 7, p. 131-142, mar.-apr. 


\section{D) \\ UMA TEORIA MARXISTA DO POLÍTICO? O DEBATE BOBBIO TRENT'ANNI DOPPO}

\section{ALVARO BIANCHI}

O debate aberto por Norberto Bobbio há 30 anos por meio de uma série de artigos publicados na revista Mondoperaio levantava dois desafios à teoria marxista da política: 1) Existe uma teoria marxista da política? 2) Quais as alternativas à democracia representativa? O debate revelou, por um lado, um elevado grau de consenso sobre os valores e as regras da democracia liberal e, por outro, a inexistência entre os participantes do debate de uma teoria política antagônica à teoria política liberal-constitucionalista. $\mathrm{O}$ presente artigo discute esse debate e desenvolve a hipótese de que apenas como teoria política negativa o marxismo poderia constituir uma crítica da política que se afirmasse como o programa teórico da superação da teoria política de sua época e como o programa prático da superação da própria política.

Palavras-chave: Norberto Bobbio; Marxismo ; Teoria política.

\section{IS THERE A MARXIST THEORY OF POLITICS? THE BOBBIO DEBATE TRENT'ANNI DOPPO}

The debate opened thirty years ago by Norberto Bobbio with a series of articles published by the Mondoperaio magazine raised two challenges to the Marxist theory of politics: 1)Is there a Marxist theory of politics? 2) Which are the alternatives to representative democracy? On the one hand, the debate has revealed a high level of consensus on the values and rules of liberal democracy and, on the other hand, the absence among the participants of the debate of a political theory antagonistic to the constitutional-liberal one. This article deals with this debate and develops the hypothesis that only as a negative political theory Marxism could be a critique of politics, being consolidated as the theoretical program for the overcoming 
Resumos / Abstracts

of the political theory of its age and as the practical program of overcoming politics proper.

Keywords: Norberto Bobbio; Marxism; Political theory. 